\title{
Pembangunan Kemandirian Desa Berbasis Masyarakat melalui Pemanfaatan Dana Desa di Kabupaten Blora
}

\section{Development of Community-Based Village Independence through The Use of Village Funds in Blora Regency}

\author{
Aji Rayi Purwasih ${ }^{1}$ dan Retno Sunu Astuti \\ Departemen Administrasi Publik, FISIP Universitas Diponegoro \\ Jl. Prof. Soedarto, SH., Tembalang, Semarang, Jawa Tengah \\ No. Telp dan Fax: (+6224) 7465407 \\ (Diterima 26/10/20; disetujui: 19/05/21)
}

\begin{abstract}
This study aims to analyze efforts to develop village self-reliance that was oriented towards community empowerment through the use of village funds that were distributed to each village in Blora Regency. This study used a descriptive method with a qualitative approach based on secondary data sources, which included official documents from related agencies and previous related research. The data analysis technique that guides researchers included three stages, namely data reduction or conceptual framework preparation, data presentation and preparation, and drawing detailed conclusions. This study concludes that the utilization of village funds used to support the development of village independence was carried out through community empowerment. This study recommends that Blora Regency has the opportunity to manage village funds that aim to increase community empowerment by examining indicators of success in increasing public awareness in a participatory manner in the development planning process (musrenbangdes); developing and strengthening community strength with village funds as a priority activity to optimize village resource management, and community protection carried out by the government and village institutions as a companion by establishing policies and community activity programs through village funds. The achievement of the use of village funds sourced from the national budget (APBN) is intended as the dynamic support for villages in building community-based independence.
\end{abstract}

Keywords: community-based development, village autonomy, optimization of village funds

\begin{abstract}
Abstrak
Penelitian ini bertujuan untuk menganalisis upaya pembangunan kemandirian desa yang berorientasi pada keberdayaan masyarakat melalui pemanfaatan dana desa yang disalurkan kepada masing-masing desa di Kabupaten Blora. Penelitian ini menggunakan metode deskriptif dengan pendekatan kualitatif yang dilakukan berdasarkan sumber data sekunder melalui teknik pengumpulan data berupa dokumentasi yang mencakup dokumen resmi dari instansi terkait dan penelitian terdahulu yang relevan. Teknik analisis data yang menjadi pedoman peneliti
\end{abstract}

\footnotetext{
${ }^{1}$ Email: ajirayi.purwasih@gmail.com
} 
meliputi tiga tahapan, yaitu reduksi data atau penyusunan kerangka konseptual, penyajian dan penyusunan data, serta penarikan kesimpulan secara mendetail. Hasil pada penelitian ini menyimpulkan bahwa pemanfaatan dana desa yang digunakan untuk menunjang pembangunan kemandirian desa dijalankan melalui pemberdayaan masyarakat. Kabupaten Blora memiliki peluang dalam pengelolaan dana desa yang diarahkan untuk meningkatkan keberdayaan masyarakat dengan meninjau indikator keberhasilan pada peningkatan kesadaran masyarakat secara partisipatif dalam proses perencanaan pembangunan; pengembangan dan penguatan daya masyarakat dengan dana desa untuk prioritas kegiatan optimalisasi pengelolaan sumber daya desa; dan perlindungan masyarakat yang dijalankan oleh pemerintah dan kelembagaan desa sebagai pendamping dengan menetapkan kebijakan dan program kegiatan masyarakat melalui dana desa. Ketercapaian penggunaan dana desa yang berasal dari APBN ditujukan sebagai dukungan yang bersifat dinamis bagi desa dalam membangun kemandirian yang bertumpu pada masyarakat.

Kata Kunci: pembangunan berbasis masyarakat, otonomi desa, optimalisasi dana desa

\section{PENDAHULUAN}

Desa merupakan satuan pemerintahan yang berada pada struktur organisasi terkecil dan secara langsung berinteraksi dengan masyarakat, didasarkan atas prinsip permusyawaratan, kebersamaan, dan kekeluargaan. Prinsip tersebut tertuang dalam Undang-undang Nomor 6 Tahun 2014 tentang Desa, yang bertujuan untuk membentuk otonomi desa sebagai wujud pembangunan berkelanjutan. Pembangunan desa tercermin dari adanya desa-desa mandiri yang berkapasitas tinggi dalam mengembangkan potensi sumber daya manusia maupun sumber daya alam yang dimiliki. Desa mandiri memiliki makna bahwa desa dapat menjalankan pemerintahan otonom yang baik dalam pembangunan infrastruktur, pemberdayaan masyarakat, serta pembinaan ekonomi desa dalam peningkatan kesejahteraan masyarakat.

Meninjau kemandirian desa, berkaitan erat dengan kemampuan masyarakat sebagai subjek pembangunan dalam berpartisipasi mengembangkan potensi desa. Pembangunan desa yang bertumpu pada masyarakat mengarah pada pembinaan masyarakat dari aspek sosial dan ekonomi untuk mengembangkan kemandirian dan kesejahteraan. Peningkatan peran masyarakat menjadi dasar dalam kemandirian desa yang bersifat jangka panjang melalui pengetahuan dan keterampilan dalam mengelola sumber daya desa untuk menghasilkan modal pembangunan. Peran masyarakat dijalankan melalui keberdayaannya yang mengarah pada prinsip gotong-royong dalam masyarakat untuk mengembangkan desa mandiri dan sejahtera. Upaya pemberdayaan masyarakat tersebut ditinjau dari kekuatan lokal yang mengacu pada kapasitas masyarakat, dimulai dari proses penyadaran untuk membentuk komitmen dalam masyarakat dengan dukungan pemerintah desa dan komunitas sebagai kelembagaan yang menggerakkan pembangunan desa (Dwiyanto \& Jemadi, 2013).

Pembangunan kemandirian desa berbasis masyarakat mengacu pada arah kebijakan dan sasaran pada Rencana Pembangunan Jangka Menengah (RPJM) Kemendesa PDTT Tahun 2020-2024 yang mengupayakan peningkatan kapasitas desa guna mempercepat pembangunan perdesaan. Proses pengembangan tersebut diarahkan pada usaha untuk mengentaskan desa tertinggal, dijalankannya pembangunan fisik dan pemberdayaan masyarakat menuju mandiri. Secara nasional, data Indeks Pembangunan Desa (IPD) melakukan pemetaan kemajuan desa di suatu wilayah tertentu dengan mengklasifikasikan desa berdasarkan tiga tingkat yaitu: desa berstatus tertinggal; berkembang; dan mandiri. 
Pada kajian IPD tahun 2018 oleh Bappenas dan BPS, terdapat 75.436 desa dengan proporsi paling tinggi, yaitu desa berkembang sebesar $73.40 \%$ diikuti dengan desa tertinggal sebesar $19,17 \%$ dan jumlah paling rendah ada dalam status desa mandiri, yaitu 7,43\%. Persentase jumlah desa berdasarkan status IPD menggambarkan adanya persoalan di desa yang memerlukan dorongan untuk membangun kemandirian desa (Prastiwi et al, 2019).

Berbicara mengenai pembangunan desa, Kabupaten Blora menjadi wilayah di Provinsi Jawa Tengah dengan tingkat IPD rendah di bawah rata-rata provinsi yaitu $62,22 \%$ sedangkan Provinsi Jawa Tengah memiliki nilai 67,37\%. Kabupaten Blora memiliki 271 desa dan terdapat lima desa dengan status desa tertinggal. Berdasarkan data IPD, jumlah desa mandiri di Kabupaten Blora mengalami penurunan, terlihat dari pemetaan IPD Tahun 2014 terdapat 12 desa mandiri sedangkan untuk status desa mandiri pada tahun 2018 berkurang menjadi 9 desa. Berdasarkan kondisi permasalahan di Kabupaten Blora, penurunan status desa mandiri disebabkan pada keterbatasan kapasitas sumber daya manusia serta rendahnya kesadaran dan komitmen masyarakat desa untuk berpartisipasi dalam pembangunan desa (Prastiwi et al, 2019). Oleh karena itu, kemandirian desa serta pengembangan kapasitas masyarakat menjadi isu penting dalam penyusunan Rencana Strategis (Renstra) Pemerintah terutama Dinas Pemberdayaan Masyarakat dan Desa Kabupaten Blora Tahun 2017-2021.

Tujuan mewujudkan kemandirian desa di Kabupaten Blora dijalankan dengan menerapkan indikator yang tertuang dalam perencanaan strategis daerah, yaitu dengan pemanfaatan dana desa sebagai sumber keuangan desa. Program dana desa merupakan dana dari APBN untuk membiayai pelaksanaan pemerintahan, pembangunan infrastruktur, serta pembinaan dan pemberdayaan masyarakat. Penyaluran dana desa di Kabupaten Blora diarahkan pada Peraturan Bupati Blora No. 22 Tahun 2020 tentang Perubahan atas Peraturan Bupati Blora No. 65 Tahun 2019 tentang Tata Cara Pembagian dan Perincian Dana Desa Setiap Desa di Kabupaten Blora Tahun 2020. Tujuannya mengacu pada upaya memperkuat kapasitas masyarakat desa sebagai subjek dari pembangunan desa melalui prioritas pemberdayaan.

Pada pelaksanaannya, penyaluran dana desa dilakukan melalui permohonan pencairan yang diajukan oleh Pemerintah Desa dan penggunaannya disesuaikan dengan kebutuhan pembangunan desa. Penyaluran dana desa di Kabupaten Blora selama lima tahun (2016-2020), mengalami kenaikan secara signifikan pada realisasi penyerapan dana desa oleh daerah, berdasarkan laporan realisasi anggaran pendapatan dana desa yang mencapai $100 \%$. Kenaikan perolehan dana desa secara dinamis menjadi modal dalam pembangunan desa secara fisik maupun nonfisik yang berbasis pada kapasitas masyarakat (PPID Kabupaten Blora, 2019). Masyarakat memiliki peran dalam mendukung capaian kemandirian desa terutama melalui dana desa, hal ini mengarah pada kondisi sosial dan ekonomi masyarakat yang secara dasar telah terpenuhi karena perencanaan yang disusun berdasarkan pada kebutuhan dan usulan masyarakat. Pembangunan fisik yang dilakukan juga memerlukan respons positif dari masyarakat secara optimal agar bermanfaat secara jangka panjang (Sofianto, 2017).

Dukungan dana desa menjadi dasar dalam membangun keberhasilan pengelolaan sumber daya terutama pada kapasitas masyarakat. Program pemenuhan kebutuhan desa melalui dana desa difungsikan sebagai stimulan bagi pemerintah dan masyarakat desa untuk mendayagunakan dana perimbangan dalam mewujudkan penyelenggaraan otonomi desa. Dana desa menjadi bantuan yang memiliki esensi bagi desa untuk memenuhi hak dalam penyelenggaraan pembangunan desa (Karimah et al, 2014). Kenaikan jumlah penyaluran dana desa di Kabupaten Blora ditujukan sebagai peluang bagi desa untuk membangun kemandirian desa yang berorientasi pada masyarakat. Realisasi penyaluran dana desa pada program pemberdayaan masyarakat diarahkan untuk meningkatkan kesadaran masyarakat dalam berpartisipasi pada pembangunan desa. Selain itu, dana desa 
juga digunakan untuk pengembangan kemampuan masyarakat dalam mengelola potensi lokal serta menjadi modal dalam penyelesaian permasalahan pembangunan di perdesaan (Kemenkeu, 2017).

Perwujudan kemandirian desa menjadi perhatian penuh pemerintah daerah dan desa serta masyarakat. Hal ini berkaitan dengan kendala perwujudan kemandirian desa dari sisi masyarakat. Berdasarkan isu strategis pembangunan desa yang terdapat dalam Renstra Dinas PMD Blora, tahun 2019, permasalahan yang muncul, yaitu masih tingginya tingkat ketergantungan masyarakat terhadap pemerintah dalam pembangunan desa serta rendahnya partisipasi dan kapasitas masyarakat dalam menciptakan pengelolaan sumber daya dan potensi lokal. Berkaitan dengan hal tersebut, fungsi masyarakat dalam mendukung kemandirian desa sering kali menimbulkan persoalan mengenai minimnya kesadaran masyarakat untuk meningkatkan daya dukung pembangunan tanpa bantuan pemerintah, terutama secara finansial (Hasyim, 2019). Oleh karena itu, melalui dana desa sebagai stimulan, agar dimanfaatkan tidak hanya pada pembangunan fisik desa, akan tetapi perlu adanya keberanian desa dalam membangun kekuatan lokal yang berfokus pada keberdayaan masyarakat.

Berdasarkan data dan permasalahan yang telah dijabarkan, diketahui bahwa terdapat isu penting mengenai keberdayaan melalui kapasitas masyarakat dalam menunjang kemandirian desa. Penelitian ini memiliki arah kajian untuk menganalisis pembangunan kemandirian desa berbasis masyarakat melalui dukungan dana desa sebagai stimulus pembangunan desa dan kesejahteraan masyarakat serta mencermati adanya hambatan dalam membangun kemandirian desa yang bertumpu pada masyarakat.

\section{TINJAUAN TEORETIS DAN PENELITIAN SEBELUMNYA}

\subsection{Pembangunan Kemandirian Desa}

Pembangunan secara umum merupakan suatu proses dinamis yang ditujukan untuk mencapai kesejahteraan masyarakat pada tingkat yang lebih tinggi. Pembangunan sebagai kemauan dan kemampuan internal dalam masyarakat yang bersangkutan menjadi proses yang berkaitan dengan upaya meningkatkan produktivitas dalam tatanan kemasyarakatan. Adisasmita (Rahman, 2016) menyebutkan bahwa pembangunan erat kaitannya dengan partisipasi anggota masyarakat, meliputi berbagai proses baik dalam perencanaan, implementasi dan monitoring program pembangunan, yang dalam penerapannya dinilai kompleks.

Menurut Suparjan \& Suyatno (2003), pembangunan pada dasarnya bertujuan untuk memajukan desa beserta masyarakatnya secara terpadu, guna meningkatkan kesejahteraan masyarakat dan memperbaiki kualitas hidup dan kemandirian masyarakat (Diah \& Syawie, 2015). Pembangunan desa sebagai bentuk intervensi yang bertujuan mengurangi tingkat ketimpangan dan kesenjangan antar-wilayah perdesaan dan perkotaan sebagai akibat dari pembangunan ekonomi sebelumnya yang dominan terhadap perkotaan. Pembangunan desa dijadikan sebagai solusi peningkatan sosial ekonomi masyarakat untuk menunjang perubahan yang mengarah pada pembangunan berkelanjutan. Barokah dkk. (2015) menjelaskan bahwa prioritas pembangunan perdesaan (rural-based development) memiliki aspek-aspek yang perlu diperhatikan, yaitu meliputi: a) pengembangan kapasitas dan pendampingan aparatur pemerintah desa dan kelembagaan pemerintahan secara berkelanjutan; b) pemenuhan standar pelayanan minimum desa sesuai dengan kondisi wilayah; c) penanggulangan kemiskinan dan pengembangan usaha ekonomi masyarakat desa; d) pembangunan sumber daya manusia melalui pemberdayaan masyarakat berbasis pada modal sosial budaya; e) pengelolaan potensi sumber daya alam dan lingkungan hidup yang berkelanjutan; f) pengembangan ekonomi kawasan perdesaan; dan g) monitoring 
peraturan UU Desa secara sistematis dan konsisten melalui koordinasi serta pendampingan (Barokah et al., 2015). Prioritas pembangunan perdesaan tersebut mengarah pada kunci sukses dalam memajukan desa serta menciptakan kemandirian desa.

Secara umum, kemandirian desa memiliki makna dalam pembangunan sebagai desa yang otonom dan memiliki kemampuan dan kualitas dalam menyelenggarakan pemerintahannya. Selain itu, Hillery berpendapat mengenai masyarakat sebagai subjek pembangunan, menjadi kekuatan desa melalui keberdayaan dalam ikatan kebersamaan dan memiliki interaksi yang berkelanjutan. Kemandirian desa berkaitan dengan pemberdayaan desa dalam meningkatkan kapasitas pengelolaan potensi lokal serta kemampuan untuk menyelesaikan permasalahan pembangunan desa baik secara fisik maupun nonfisik melalui masyarakat yang juga berkapasitas tinggi (Diah \& Syawie, 2015). Berdasarkan Undangundang No. 6 Tahun 2014 tentang Desa menjelaskan bahwa terdapat sifat masyarakat desa yang mengarah pada prinsip kebersamaan dan gotong-royong dalam menyelenggarakan kegiatan pembangunan desa menuju desa mandiri dan sejahtera.

Berkaitan dengan tujuannya, Mardhiah (2017) mengemukakan pembangunan desa dijalankan berdasarkan unsur yang diarahkan pada peningkatan kesejahteraan dan taraf hidup yang mencakup perluasan akses masyarakat dalam usaha ekonomi produktif; keberdayaan masyarakat perdesaan melalui peningkatan kualitasnya; serta penguatan kelembagaan melalui modal sosial berupa jaringan kerja sama. Selain itu adanya upaya meningkatkan kesejahteraan masyarakat melalui hak dasar. Tujuan dalam pembangunan perdesaan yang berfokus pada pemberdayaan masyarakat untuk mencapai suatu keadaan pertumbuhan dan peningkatan untuk kondisi jangka panjang serta peningkatan kualitas kehidupan masyarakat baik dalam aspek mental, fisik, keterampilan serta kesadaran berpartisipasi dalam program pembangunan (Mardhiah, 2017).

Pemahaman mengenai kemandirian desa dalam penelitian ini mengacu pada faktor ekonomi masyarakat, sosial budaya, dan ekologi wilayah, yang ketiganya berpengaruh terhadap proses pembangunan yang berkelanjutan. Berdasarkan penjabaran dari konsep dan aspek-aspek yang dikemukakan sebelumnya, maka diketahui bahwa peningkatan taraf hidup masyarakat dijadikan acuan dalam mendukung capaian pembangunan kemandirian desa yang memiliki tujuan untuk mengurangi adanya kesenjangan desa yang ditinjau dari kapasitas sumber daya alam maupun manusia. Upaya kemandirian desa yang mengarah pada kekuatan lokal juga menjadi dasar dalam menyelesaikan berbagai persoalan pembangunan yang bersifat multidimensi melalui pengembangan kemampuan sumber daya manusia secara berkelanjutan.

\subsection{Pemberdayaan Masyarakat}

Masyarakat (community) dalam suatu tatanan perdesaan yang berperan sebagai subjek pembangunan secara berkelanjutan memiliki modal sosial dalam pembangunan desa atas dasar sifat gotong-royong dan kekeluargaan. Fungsinya dalam mengembangkan kemandirian desa didasarkan pada kapasitas yang muncul melalui pemberdayaan. Pemberdayaan masyarakat memiliki makna luas baik dalam upaya pemenuhan kebutuhan dasar masyarakat meliputi sandang, pangan, dan papan, serta secara lebih dalam menyangkut perannya dalam mengentaskan kemiskinan dan menciptakan pembangunan jangka panjang (Firmansyah, 2012).

Pada proses pembangunan, masyarakat dilibatkan secara penuh dan aktif agar dapat berpartisipasi mengembangkan sumber daya desa. Widjajanti (2011) memaknai adanya sumbangan kekuatan dalam masyarakat yang disalurkan dalam pemberdayaan secara berkelanjutan untuk menjalankan proses melalui pengetahuan dan keterampilan dalam tahap identifikasi, analisis, serta penetapan kebutuhan dalam pengelolaan sumber daya 
desa serta optimalisasi kekuatan dalam tatanan masyarakat untuk menyelesaikan masalah pembangunan desa yang dihadapi (Widjajanti, 2011). Parson menyebutkan definisi pemberdayaan yang mengarah pada proses bagi masyarakat untuk berpartisipasi dalam segala penyelenggaraan pembangunan baik dalam proses perencanaan, pelaksanaan, serta evaluasi atau pengontrolan. Hal ini dapat diperoleh dengan memberdayakan masyarakat untuk menciptakan wawasan yang luas dan kemampuan dalam setiap sisi dari tujuan pembangunan (Maspaitella \& Rahakbauwi, 2014).

Berdasarkan serangkaian definisi dan pemaknaan pada pemberdayaan masyarakat, dijelaskan bahwa secara umum pemberdayaan atau keberdayaan masyarakat dalam lingkup pemerintahan baik pusat sampai dengan tingkat RT. Fungsi masyarakat dijadikan sebagai prioritas pembangunan karena adanya pemenuhan hak dasar di bidang ekonomi, sosial, politik, budaya, pendidikan, kesehatan maupun lingkungan melalui kapasitas serta kemandirian masyarakat. Oleh karena itu, pemberdayaan masyarakat menjadi suatu pendekatan yang dijalankan dalam proses pembangunan yang mempersyaratkan kapasitas sumber daya masyarakat yang mandiri dan berpotensi tinggi. Pada perjalanannya, masyarakat tidak dibiarkan dalam menemukan kemampuan sendiri, terdapat dukungan kelembagaan secara luas untuk membantu proses pendayagunaan kekuatan lokal melalui pemberdayaan. Masyarakat yang tidak diberdayakan akan memunculkan kondisi di tahap keterpurukan yang disebabkan tidak adanya upaya meningkatkan kesejahteraan. Masyarakat memiliki keterbatasan yang dipengaruhi oleh faktor internal, yaitu sosial budaya serta kemampuan dasar dari fisik masyarakat, sedangkan dari faktor eksternal terdiri dari ekonomi, teknologi serta faktor kondisi geografis lingkungan (Mulyawan, 2016).

Pada upaya melengkapi keterbatasan masyarakat, dilakukan dengan strategi pemberdayaan yang berkonsep pada indikator keberhasilan dalam keberdayaan masyarakat. Soeharto mengemukakan adanya empat indikator dalam mengukur tingkat keberdayaan masyarakat, yaitu: 1) tingkat kesadaran dan kemauan masyarakat untuk memahami suatu perubahan; 2) tingkat kapasitas masyarakat dalam mendapatkan peluang kesejahteraan; 3) tingkat kapasitas dalam menghadapi kendala dan hambatan yang menjadi tantangan dalam pemberdayaan; dan 4) tingkat kemampuan menjalin kemitraan dan kolaborasi untuk mencapai pembangunan (Firmansyah, 2012). Berbeda dengan empat dimensi tersebut, Friedman (1992) juga berpendapat bahwa konsep serta unsur yang diperlukan dalam proses pemberdayaan meliputi pengembangan yang berorientasi pada masyarakat, pengembangan kapasitas secara berkelanjutan, menumbuhkan partisipasi masyarakat, penguatan modal sosial masyarakat serta mengentaskan kemiskinan dan ketimpangan dari sisi gender (Friedman, 1992).

Selanjutnya, Kartasasmita mengupayakan kesuksesan dari proses keberdayaan masyarakat melalui tiga indikator, sebagai berikut:

1. Enabling, merupakan unsur pemberdayaan dalam menciptakan suasana atau iklim yang mendukung masyarakat untuk menggali potensi secara mandiri. Prosesnya dijalankan melalui pemberian informasi serta motivasi bagi masyarakat sebagai bentuk penyadaran akan pentingnya pengembangan kapasitas sumber daya;

2. Empowering, kunci pemberdayaan masyarakat adalah pada penguatan kemampuan yang dilihat dari berbagai aspek untuk mendapatkan peluang keberhasilan dalam pemberdayaan, baik dari pembangunan fisik maupun nonfisik sebagai pelatihan dan peningkatan keterampilan masyarakat;

3. Protecting, unsur melindungi masyarakat dalam proses pemberdayaan diarahkan pada tujuan untuk memberikan keberhasilan bagi masyarakat dalam membangun potensi secara berkelanjutan. Hal ini berkaitan dengan adanya kebijakan yang memihak kepada masyarakat agar tidak dimarginalkan dalam tatanan pembangunan (Mulyawan, 2016). 
Dimensi atau indikator tersebut menjadi sarana bagi masyarakat untuk berdaya guna serta memiliki peran aktif dalam pembangunan yang didasarkan pada otoritas pemberdayaan yang berada di lingkup masyarakat. Indikator keberdayaan masyarakat juga menjadi acuan dalam keberhasilan masyarakat desa membangun kemandirian desa melalui berbagai program dan kegiatan yang mengarah pada upaya pembangunan desa.

Pemberdayaan masyarakat menjadi bagian dari proses capacity building yang bersifat jangka panjang serta mendorong kemampuan masyarakat dalam memetakan berbagai isu pembangunan melalui proses perencanaan, pelaksanaan, serta pengawasan agar tujuan untuk mewujudkan kesejahteraan masyarakat dapat tercapai. Berdasarkan konsep dan dimensi-dimensi dalam pemberdayaan masyarakat, penelitian ini mengacu pada upaya yang dijalankan dalam berbagai indikator capaian peningkatan kapasitas masyarakat untuk mendukung kemandirian desa melalui kebijakan dan program yang diselenggarakan guna mencapai pembangunan yang dinamis dan berkelanjutan.

\subsection{Dana Desa}

Definisi mengenai dana desa dijelaskan pada Peraturan Pemerintah Nomor 8 Tahun 2016 Perubahan Kedua Atas Peraturan Pemerintah Nomor 60 Tahun 2014 tentang Dana Desa yang Bersumber dari Anggaran Pendapatan dan Belanja Negara merupakan dana yang bersumber dari anggaran belanja negara yang diperuntukkan bagi desa yang disalurkan melalui APBD dan digunakan untuk membiayai penyelenggaraan pemerintahan, pelaksanaan pembangunan, pembinaan kemasyarakatan, dan pemberdayaan masyarakat. Dana desa merupakan modal bagi desa yang dikelola oleh pemerintah desa beserta perangkat desa serta melibatkan masyarakat untuk berpartisipasi dalam serangkaian tahapan pembangunan desa yang bertujuan untuk mengawal penyerapan dana desa bagi masing-masing desa. Pengelolaan dana desa menjadi bagian yang melekat pada perencanaan anggaran daerah untuk menunjang kemandirian desa dan pemberdayaan masyarakat. Sistem ter-input dalam proses perencanaan pembangunan desa melalui Musyawarah Perencanaan Pembangunan Desa (Musrenbangdes) dengan melibatkan partisipasi masyarakat (Sofiyanto et al, 2017).

Pada pelaksanaannya, program dana desa sebagai sumber pendanaan bagi desa dalam menunjang pembangunan infrastruktur dan pengembangan kapasitas masyarakat melalui pemberdayaan. Tujuan dana desa diarahkan untuk meningkatkan proses pelayanan publik di tingkat desa, penanggulangan kemiskinan, peningkatan perekonomian desa sebagai tonggak kesejahteraan masyarakat, mengatasi ketimpangan pembangunan serta penguatan kapasitas masyarakat. Berdasarkan Undang-Undang No. 6 Tahun 2014, dana desa disalurkan kepada pemerintah desa yang dialokasikan menurut jumlah penduduk, angka kemiskinan, luas wilayah, dan geografis desa. Penggunaan dana desa diarahkan pada prinsip-prinsip yang meliputi: keadilan, kebutuhan prioritas, kewenangan desa, partisipatif, swakelola dan berbasis sumber daya desa serta tipologi desa (Kemenkeu, 2017).

Dana desa merupakan bentuk program Pemerintah Pusat dari sisi pendapatan yang menunjang pembangunan dan kesejahteraan masyarakat. Posisi dana desa diberikan sebagai upaya penguatan desa dalam menggali dan mengelola sumber daya yang tersedia. Dana desa ditetapkan dalam kerangka kebijakan baik secara tertulis berupa UndangUndang dan peraturan maupun melalui program dan kegiatan yang diselenggarakan oleh pemerintah (Noverman, 2018). Pemanfaatan dana desa dijadikan sebagai stimulan bagi desa untuk membangun kemandirian desa secara optimal pada pembangunan fisik desa untuk menunjang kemudahan aksesibilitas masyarakat untuk meningkatkan produktivitas dalam pengelolaan sumber daya. Arah pembangunan lain dalam pemanfaatan dana desa adalah untuk memberdayakan masyarakat yang bertujuan untuk beberapa aspek kehidupan 
masyarakat meliputi: modal usaha ekonomi produktif melalui BUMDes, dukungan kegiatan pelestarian lingkungan, pengembangan kerja sama antar desa, dukungan mitigasi bencana, serta pemberdayaan lain sesuai dengan kebutuhan masing-masing desa (Kemenkeu, 2017).

Berdasarkan penjabaran mengenai dana desa dan tujuan penerapannya, penelitian ini mengarah pada fungsi dana desa sebagai stimulan yang diberikan oleh Pemerintah Pusat dan dialokasikan melalui APBD Pemerintah Daerah kepada masing-masing desa yang dilihat dari alokasi perhitungan baik untuk desa sangat tertinggal sampai dengan desa mandiri berdasarkan indeks pembangunan desa. Arah capaian dana desa yang dicermati mencakup pembangunan fisik desa; pembinaan kesejahteraan sosial dan ekonomi; serta pemberdayaan masyarakat untuk mendukung pembangunan desa yang berkelanjutan.

\section{METODE PENELITIAN}

Desain pada penelitian ini yaitu menggunakan metode deskriptif dengan pendekatan kualitatif. Anselm Strauss \& Juliet Corbin menjelaskan bahwa penelitian kualitatif sebagai suatu atribut yang digunakan untuk memperoleh wawasan dalam menjelaskan suatu informasi dan data, selain itu juga menjadi dasar dalam memahami penyelesaian yang berkaitan dengan fenomena yang dikaji. Penelitian ini mengacu pada jenis penelitian studi kasus guna mendeskripsikan fenomena secara empiris yang ada di dalam masyarakat (Miller \& Whicker, 1998).

Penelitian ini mengkaji informasi mengenai pembangunan kemandirian desa berbasis masyarakat dengan dukungan dana desa di Kabupaten Blora. Kabupaten Blora dijadikan lokus penelitian didasarkan pada rendahnya kapasitas dalam membangun desa sesuai dengan dimensi Indeks Pembangunan Desa (IPD) terutama pada dimensi aksesibilitas; pelayanan umum; dan penyelenggaraan pemerintahan (Prastiwi et al., 2019). Hal ini berkaitan dengan proses pembangunan desa secara berkelanjutan melalui potensi desa, baik secara fisik maupun finansial, terutama yang diperoleh dari dana desa sebagai dukungan sumber pendanaan desa yang diarahkan pada proses peningkatan kapasitas masyarakat melalui pemberdayaan maupun pembangunan infrastruktur yang bersifat jangka panjang.

Sumber data yang digunakan adalah data sekunder yang berasal dari pengumpulan data dokumentasi dan sumber resmi dari lokasi penelitian mengenai fenomena yang dikaji, meliputi: buku saku dana desa tahun 2017, data indeks pembangunan desa tahun 2018, laporan realisasi anggaran pendapatan dan belanja Kabupaten Blora tahun 2019, Peraturan Bupati Blora No. 22 Tahun 2020 tentang Perubahan atas Peraturan Bupati Blora No. 65 Tahun 2019 tentang Tata Cara Pembagian dan Perincian Dana Desa di Kabupaten Blora Tahun 2020, dan Rencana Strategis Dinas Pemberdayaan Masyarakat dan Desa Tahun 20172021. Instrumen yang digunakan pada penelitian ini, yaitu peneliti itu sendiri, seperti yang dijelaskan dalam Creswell \& Poth, (2016) sebagai instrumen kunci untuk mengumpulkan sendiri data melalui sumber data yang dihasilkan dari teknik pengumpulan data dokumentasi (Creswell \& Poth, 2016).

Setelah dilakukan pengumpulan data sebagai analisis awal, selanjutnya dilakukan analisis data merujuk pada prinsip yang disampaikan oleh Miles dan Huberman (1984) meliputi tiga sub-proses analisis data, yaitu reduksi data atau penyusunan kerangka konseptual, penyajian data atau penyusunan informasi menjadi bentuk data terpadu, serta kesimpulan sebagai gambaran secara detail mengenai makna dari sebuah data yang disajikan (Yang \& Miller, 2007). 


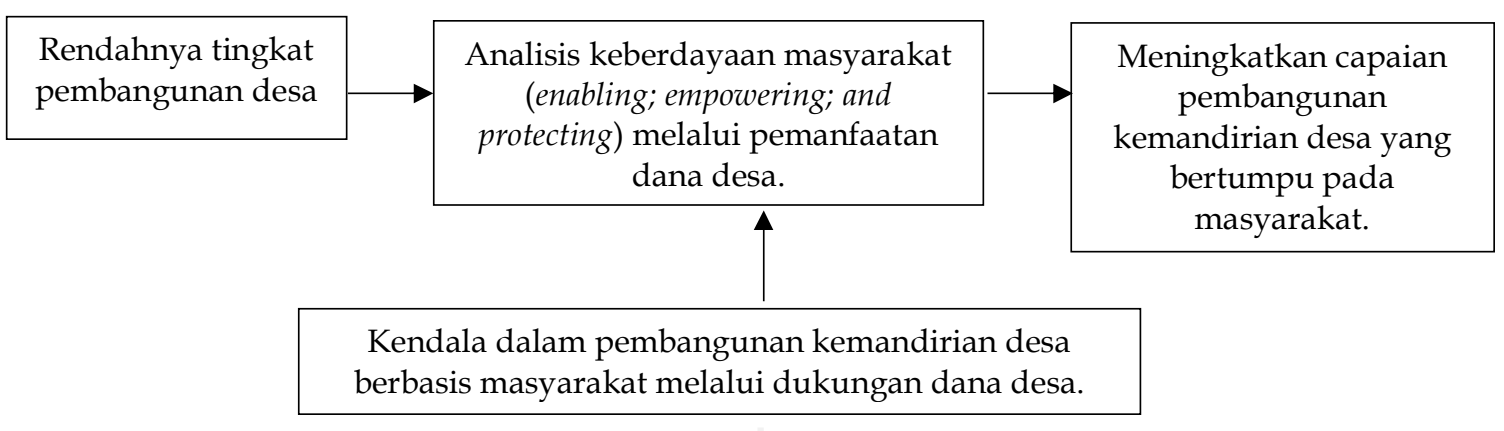

Gambar 1. Kerangka Konseptual

Sumber: Penulis, 2020.

Kerangka konseptual penelitian sebagai acuan bagi peneliti untuk menentukan fokus penelitian. Pada penelitian ini, fokus penelitian adalah pembangunan kemandirian yang bertumpu pada masyarakat melalui dukungan dan pemanfaatan dana desa di Kabupaten Blora. Adapun indikator teoretis yang digunakan untuk mendeskripsikan dan menganalisis permasalahan dalam penelitian dilihat dari indikator keberhasilan keberdayaan masyarakat dalam pembangunan kemandirian desa menurut Kartasasmita (1996) meliputi: Enabling sebagai penyadaran masyarakat, Empowering sebagai pemberdayaan masyarakat, dan Protecting sebagai bentuk perlindungan bagi masyarakat (Mulyawan, 2016).

\section{HASIL DAN PEMBAHASAN}

\subsection{Hasil Penelitian}

\subsubsection{Pengelolaan Dana Desa di Bidang Pemberdayaan Masyarakat Kabupaten Blora}

Kabupaten Blora adalah salah satu Kabupaten di Provinsi Jawa Tengah yang terletak di bagian timur Jawa Tengah dan berbatasan dengan Kabupaten Rembang di bagian utara, Kabupaten Bojonegoro di timur, Kabupaten Ngawi di selatan serta Kabupaten Grobogan di barat. Dengan luas wilayah sebesar $1.821,159 \mathrm{~km}^{2}$, secara administratif Kabupaten Blora memiliki 271 desa yang ada di 16 Kecamatan (BPS Blora, 2019).

Pelaksanaan program dana desa di Kabupaten Blora didasarkan pada kebijakan yang diterapkan mengenai tata cara pembagian dan perincian penerimaan dana desa di masing-masing desa yang disusun berdasarkan periode tahunan. Dana desa di Kabupaten Blora diorientasikan pada peningkatan kapasitas keuangan desa dalam rangka pembangunan desa. Penyaluran dana desa diarahkan pada kegiatan yang menyangkut pencapaian pembangunan desa meliputi penyelenggaraan pemerintahan desa, pembangunan infrastruktur sarana dan prasarana penunjang kegiatan masyarakat, pemberdayaan masyarakat guna menciptakan kemandirian desa serta pembinaan baik dalam aspek sosial dan ekonomi untuk mewujudkan kesejahteraan masyarakat.

Berbicara mengenai pembangunan desa, Kabupaten Blora berada pada posisi kuadran IV dalam tipologi perkembangan daerah berdasarkan pendapatan daerah dan pembangunan manusia. Kuadran IV menandakan adanya pembangunan manusia dalam 
kategori rendah dan pendapatan daerah yang juga rendah. Hal ini menunjukkan adanya ketimpangan dalam tatanan masyarakat untuk membangun kesejahteraan di berbagai aspek kehidupan. Posisi Kabupaten Blora yang ditunjukkan dengan tingkat pembangunan yang rendah disebabkan karena sebagian besar wilayahnya berupa perdesaan sehingga terdapat kesenjangan dengan wilayah perkotaan (Mafruhah et al, 2018). Oleh karena itu, melalui dukungan dana desa menjadi bagian dari upaya pembangunan masyarakat untuk menunjang pembangunan kemandirian desa yang termuat dalam indikator tujuan utama perencanaan strategis Dinas PMD Kabupaten Blora yang disusun pada 2019.

Dana desa adalah dana perimbangan yang bersumber dari APBN kemudian ditransfer ke daerah untuk selanjutnya disalurkan kepada masing-masing desa dengan perhitungan berdasarkan perincian dana desa. Kabupaten Blora menetapkan Peraturan Bupati Blora No. 22 Tahun 2020, yang menjelaskan adanya pembagian dana desa kepada masing-masing desa yang dialokasikan atas empat bagian meliputi: alokasi dasar, alokasi afirmasi, alokasi kinerja, dan alokasi formula. Seluruh alokasi tersebut mengacu pada ketentuan yang berlaku sesuai dengan persentase kepada masing-masing desa berdasarkan kebutuhan. Penyaluran dana desa di Kabupaten Blora selama lima tahun terakhir dari 20162020 terus bertambah disesuaikan dengan kebutuhan desa yang dilaksanakan melalui Musrenbang dari desa, kecamatan, sampai dengan kabupaten. Hal ini juga berkaitan dengan laporan kegiatan Dinas PMD Blora tahun 2020 mengenai pelatihan yang dilaksanakan oleh Pemerintah Daerah dan ditujukan kepada seluruh Kepala Desa di Kabupaten Blora secara berkala.

Tabel 1. Penerimaan Dana Desa Kabupaten Blora Tahun 2016-2020

\begin{tabular}{ccc}
\hline No. & Tahun & Pagu Dana Desa (ribuan) \\
\hline 1 & 2016 & 167.873 .329 \\
\hline 2 & 2017 & 214.102 .024 \\
\hline 3 & 2018 & 229.074 .481 \\
\hline 4 & 2019 & 268.253 .846 \\
\hline 5 & 2020 & 270.000 .037 \\
\hline
\end{tabular}

Sumber: Pusat Kajian Akuntabilitas Keuangan Negara, 2018 \& Perincian Dana Desa Kabupaten Blora Tahun 2018-2020 (diolah).

Penerimaan dana desa tersebut memiliki persentase kenaikan yang fluktuatif mengikuti kebutuhan pembangunan desa di setiap periode tahun terkait yang didasarkan pada masing-masing desa. Penyaluran dana desa dijalankan melalui tiga tahapan, yaitu tahap I dan tahap II masing-masing $40 \%$ dan tahap III sebesar $20 \%$ selama satu tahun periode anggaran.

Berdasarkan dokumentasi laporan realisasi anggaran, alokasi dasar yang diberikan kepada masing-masing desa sebagai alokasi minimal penerimaan dana desa kepada desa secara adil dan merata yang dihitung dari penerimaan daerah dibagi dengan jumlah keseluruhan desa. Di Kabupaten Blora, alokasi dasar diberikan sebesar hampir 70\% dari total penerimaan dana desa daerah. Pada tahun 2019 Kabupaten Blora menerima dana desa sebesar 268,2 miliar dengan perhitungan alokasi dasar sebesar 672,4 juta yang pasti diterima oleh masing-masing desa. Sisanya diarahkan pada alokasi yang bersifat khusus sesuai kebutuhan desa. Penyaluran yang diarahkan pada pembangunan dan upaya pengentasan desa tertinggal serta desa sangat tertinggal dengan kuantitas penduduk miskin tinggi. Alokasi tersebut dibagikan secara proporsional guna memberikan sumber pendanaan. 
Penyaluran dana desa pada tahun 2019 diterima oleh 271 desa di Kabupaten Blora dengan jumlah keseluruhan sebesar Rp268.253.846.000 dengan realisasi atau penyerapan anggaran disalurkan secara penuh dalam tiga tahapan. Data tersebut diperoleh dari Laporan Realisasi Anggaran Kabupaten Blora yang masuk dalam sumber pendanaan untuk pembangunan desa di bidang fisik atau sarana dan prasarana desa serta pemberdayaan masyarakat melalui peningkatan kapasitas terutama di sektor usaha ekonomi produktif. Pemanfaatan dana desa yang diarahkan pada pelaksanaan pemberdayaan masyarakat menjadi sasaran Dinas PMD Blora, yang ditujukan sebagai bagian swakelola dana desa untuk kemandirian dan keberdayaan masyarakat perdesaan sebagaimana tercantum dalam Renstra Dinas PMD Blora yang disusun pada 2019.

Laporan Dinas PMD Blora pada 2018 menyatakan dana desa yang diarahkan untuk menunjang pembangunan desa di Kabupaten Blora tidak hanya untuk pembangunan infrastruktur, akan tetapi lebih diberdayakan untuk meningkatkan kualitas sumber daya manusia serta mendorong keberdayaan masyarakat guna kemandirian desa berdasarkan potensi yang tersedia dengan dukungan tim Program Pembangunan dan Pemberdayaan Masyarakat (P3MD). Seluruh program kegiatan yang berkaitan dengan bidang pemberdayaan masyarakat desa melalui dana desa dijelaskan dalam Peraturan Bupati Kabupaten Blora No. 63 Tahun 2018 tentang Tata Cara Pembagian dan Perincian Dana Desa di Kabupaten Blora Tahun 2019 yang disesuaikan dengan kebutuhan masing-masing desa dan disampaikan dalam Musrenbang Daerah sebagai bentuk keterlibatan masyarakat dalam pembangunan. Program dan kegiatan dalam pemberdayaan masyarakat dilihat dari berbagai aspek meliputi peningkatan kualitas dan akses terhadap pelayanan sosial dasar, pengelolaan sarana dan prasarana sesuai potensi lokal, dan pengelolaan ekonomi produktif. Seluruh kegiatan tersebut diprioritaskan melalui pembiayaan yang bersumber dari dana desa dengan perhitungan yang disesuaikan dengan masing-masing desa.

\subsection{Pembahasan}

\subsubsection{Pemberdayaan Masyarakat Desa melalui Pemanfaatan Dana Desa}

Masyarakat merupakan penggerak dalam pembangunan kemandirian desa yangditinjau dari kemampuan dan kemandirian masyarakat dalam mengembangkan potensi desa. Dorongan pemerintah menjadi perhatian, sebagai penyelenggara kegiatan yang diarahkan untuk peningkatan kapasitas masyarakat baik dalam hal pengembangan pengetahuan dan keterampilan maupun sarana dan prasarana untuk menunjang keberhasilan pembangunan. Pemerintah memberikan dukungan secara materiel berupa dukungan pendanaan serta non-materiel berupa pelatihan dan keterbukaan informasi bagi masyarakat. Berkaitan dengan hal tersebut, pemerintah memberikan stimulan berupa dana desa yang dimanfaatkan untuk meningkatkan pembangunan fisik maupun kegiatan untuk pemberdayaan masyarakat desa. Kajian analisis pada penelitian ini mengarah pada upaya pembangunan kemandirian desa yang berorientasi pada keberdayaan masyarakat yang dijalankan melalui dukungan dana desa yang diberikan kepada masing-masing desa, sesuai dengan kebutuhan dalam pengembangannya. Adapun indikator ketercapaian keberdayaan masyarakat yang dikemukakan oleh Kartasasmita meliputi: indikator pembangunan suasana atau iklim bagi masyarakat untuk berkembang, pemberdayaan atau pengembangan kapasitas, dan perlindungan (Mulyawan, 2016: 67).

a) Pembangunan iklim bagi masyarakat untuk berkembang (Enabling)

Menciptakan suasana yang memungkinkan masyarakat untuk dapat menggali kemampuan diri menjadi dimensi yang perlu dilaksanakan dalam membangun desa menuju kemandirian (Mulyawan, 2016). Hal ini berkaitan dengan motivasi bagi 
masyarakat untuk mengubah pola pikir dilandasi dengan kekuatan diri serta pengetahuan yang mengoptimalkan penyelenggaraan pembangunan. Proses dalam indikator ini mengacu pada dorongan yang diberikan kepada masyarakat untuk menemukan dan menggali daya sebagai modal untuk berkapasitas tinggi. Masyarakat diberikan dukungan untuk senantiasa membangkitkan kesadaran dan kemampuan sebagai hak dan kewajiban masyarakat dalam proses pembangunan. Dimensi enabling yang menjadi upaya pembangunan kemandirian desa yang bertumpu pada masyarakat di Kabupaten Blora dijalankan melalui dukungan dana desa sebagai pengaruh positif dalam meningkatkan kesadaran masyarakat. Dengan adanya stimulan dana desa menjadi bentuk dorongan dari pemerintah agar masyarakat desa dapat meningkatkan kemandirian dan kekuasaan untuk mengelola sumber daya dengan maksimal. Pemahaman tersebut sejalan dengan penelitian sebelumnya oleh Mursalim \& Ramdani (2016) mengenai pentingnya memberikan wawasan berupa pengenalan bagi masyarakat tentang program dan kegiatan yang berasal dari pemerintah guna membangun modal bagi kemandirian masyarakat.

Kabupaten Blora merupakan daerah yang mendapatkan sumber pendanaan bagi pembangunan desa melalui program dana desa. Penyaluran dana desa di Kabupaten Blora dinilai tinggi dan dapat dioptimalkan untuk membangun keberdayaan masyarakat. Berbicara mengenai posisi dana desa dalam meningkatkan kesadaran masyarakat dalam mewujudkan kemandirian desa dijalankan melalui keterlibatan penuh masyarakat. Peran masyarakat menjadi vital dalam proses pembangunan desa, baik dari tahap perencanaan, pelaksanaan, maupun evaluasi atau monitoring hasil pembangunan. Berdasarkan hasil penelitian, Kabupaten Blora menyelenggarakan Musrenbang yang dijalankan dari tingkat desa sampai daerah kabupaten, yang salah satunya berkenaan dengan rencana penggunaan dana desa untuk periode tahun terkait. Kebutuhan masyarakat khususnya dalam pengembangan kapasitas masyarakat, yaitu menjadi penggerak penyelenggaraan pembangunan. Selain itu, terdapat program pelatihan Kepala Desa yang mengacu pada penyerapan dan penggunaan dana desa bagi masing-masing desa. Hal ini berkaitan dengan tujuan penyaluran dana desa yang diarahkan pada pelaksanaan kemandirian desa yang berasal dari sisi masyarakat di seluruh aspek kehidupan. Berbicara mengenai dimensi penyadaran bagi masyarakat melalui dana desa, sejalan dengan penelitian sebelumnya yang berpendapat bahwa tahap membangkitkan motivasi dan kesadaran masyarakat melalui pemahaman tentang tujuan dan peraturan dalam penggunaan dana desa sebagai upaya pembangunan desa dalam ruang musyawarah. Pada tahap ini masyarakat desa memiliki pengetahuan serta kemauan untuk memanfaatkan dana desa sebagai modal dalam mencapai pembangunan kemandirian desa (Mas'ud \& Maesaroh, 2020).

b) Penguatan kemampuan masyarakat (Empowering)

Kabupaten Blora melalui Dinas Pemberdayaan Masyarakat Desa membentuk bidang pemberdayaan masyarakat yang berfungsi sebagai penyelenggara program dan kegiatan mengenai pengembangan kapasitas masyarakat. Kapasitas masyarakat berkaitan dengan upaya lebih jauh dari proses pemberdayaan masyarakat. Indikator empowering dijadikan sebagai pembangunan yang bersifat jangka panjang atau berkelanjutan. Proses dalam tahapan ini dinilai menjadi kunci apakah program kegiatan yang diselenggarakan oleh pemerintah sebagai ruang bagi masyarakat dapat berjalan dengan maksimal dan memiliki outcome yang sesuai dengan tujuan. Kartasasmita menjelaskan bahwa proses pengembangan kapasitas masyarakat menjadi bentuk penguatan kemampuan masyarakat sebagai tindak lanjut dari penyadaran yang dapat diperoleh dari pengalaman masyarakat dalam membangun desa. Tujuannya adalah 
untuk menjadikan masyarakat berdaya guna dan menjadi peluang besar menghadapi kompleksitas masalah pembangunan (Mulyawan, 2016).

Upaya pengembangan kapasitas masyarakat diarahkan pada pemanfaatan dana desa sebagai sumber pendanaan yang memberikan kekuasaan bagi masyarakat untuk mengelola sumber daya. Berdasarkan hasil penelitian, tujuan dana desa mengacu pada dua bidang penting dalam meningkatkan kemandirian desa, yaitu pembangunan infrastruktur dan pemberdayaan masyarakat. Kedua capaian tersebut dijalankan oleh Kabupaten Blora melalui dana desa yang termuat dalam peraturan yang ditetapkan. Akan tetapi, sebagai bentuk keberlanjutan kemandirian desa, penggunaan untuk pemberdayaan masyarakat perlu diprioritaskan. Hal ini mengandung makna bahwa masyarakat sebagai tumpuan dalam pembangunan perlu ditingkatkan kemampuan baik wawasan atau pengetahuan maupun keterampilan yang mendukung. Hal ini berkaitan dengan pendapat dalam jurnal relevan mengenai pemberdayaan masyarakat bahwa pemberdayaan manusia harus disetarakan dengan pembangunan fisik desa, karena dalam merawat dan mengelola infrastruktur yang telah dibangun, diperlukan keahlian dan keterampilan yang mendasar dalam diri masyarakat (Karimah et al., 2014).

Pemberdayaan masyarakat yang dijalankan dengan dukungan dana desa termuat dalam Peraturan Bupati Kabupaten Blora No. 63 Tahun 2018 tentang Tata Cara Pembagian dan Perincian Dana Desa di Kabupaten Blora Tahun 2019. Adapun sasaran kegiatan yang diselenggarakan untuk membangun keberdayaan masyarakat melalui pengelolaan dana desa, yaitu dijalankan di berbagai aspek meliputi: pengembangan layanan kesehatan, pendidikan, aksesibilitas, ekonomi, sosial budaya, dan transportasi yang bertujuan untuk kesejahteraan masyarakat. Keseluruhan program ditujukan sebagai indikator dalam memaksimalkan penyaluran dana desa guna pembangunan desa. Kabupaten Blora melalui kebijakan yang mengatur tentang pengelolaan dana desa memiliki usaha dalam memperkuat kapasitas masyarakat dengan menerapkan program dan kegiatan yang mengarah pada kemampuan masyarakat untuk menunjang kemandirian. Pemahaman tersebut relevan dengan penjelasan pada penelitian sebelumnya yang berpendapat bahwa persoalan mengenai kemandirian desa berawal dari peran masyarakat secara penuh dalam menggerakkan program pemerintah bermodalkan pengetahuan dan keterampilan untuk menciptakan pembangunan desa mandiri dan sejahtera, yang didorong dengan dukungan pemerintah secara aktif dan optimal (Diah \& Syawie, 2015). Oleh karena itu, adanya gerakan dengan basis kolaboratif antara pemerintah dan masyarakat menjadi landasan dalam keberhasilan upaya pengembangan kapasitas bagi masyarakat.

c) Perlindungan bagi masyarakat (Protecting)

Tingkat keberhasilan upaya keberdayaan masyarakat yang ditujukan untuk membangun kemandirian masyarakat dan desa tidak terlepas dari peran pemerintah sebagai pendamping dan pelindung masyarakat. Indikator perlindungan menjadi capaian apakah proses penyadaran dan pengembangan kapasitas dalam pemberdayaan masyarakat dapat berjalan dengan optimal dan berkelanjutan. Perlindungan masyarakat dimaknai sebagai dukungan pemerintah bagi masyarakat untuk berkembang dan berkapasitas, bukan sebagai bantuan yang menimbulkan adanya ketergantungan bagi masyarakat dan berdampak pada ketidakberdayaan masyarakat. Tujuan perlindungan dalam pemberdayaan masyarakat, yaitu untuk menguatkan peran masyarakat agar mampu untuk berdaya saing dan berpartisipasi secara aktif dalam hal pembangunan (Mulyawan, 2016). Sejalan dengan pengertian indikator protecting bagi masyarakat, Kabupaten Blora mengupayakan pembangunan kemandirian desa dengan memaksimalkan modal yang diberikan oleh pemerintah secara finansial, berupa dana desa untuk dijadikan stimulan bagi masyarakat agar lebih berdaya guna. 
Realisasi penyerapan dana desa yang disalurkan secara penuh menandakan bahwa pemerintah, khususnya Pemerintah Daerah memiliki kewajiban untuk mendukung proses pembangunan kemandirian masyarakat dan desa. Selain itu, berdasarkan hasil penelitian di Kabupaten Blora, dari segi kepemimpinan mendukung pembangunan desa dan pemberdayaan masyarakat dengan menetapkan berbagai kebijakan dan atau peraturan yang berisi ketentuan dan acuan dalam proses pemberdayaan. Masyarakat desa di Kabupaten Blora pada dasarnya masih memiliki sifat bergantung dengan bantuan pemerintah sehingga mengandalkan pemerintah dalam setiap pelaksanaan program pembangunan. Permasalahan tersebut membuktikan bagaimana pentingnya perlindungan bagi masyarakat, baik melalui pelatihan maupun pendampingan dalam mengawal penggunaan dana desa untuk pembangunan dan pemberdayaan masyarakat. Penjelasan tersebut berkaitan dengan penelitian sebelumnya mengenai permasalahan dalam pemberdayaan masyarakat dipengaruhi oleh ketidaksesuaian dalam proses pembangunan bagi masyarakat. Hal ini dapat disebabkan karena minimnya keterbukaan informasi dan kurangnya kemampuan pemerintah untuk memberikan pemahaman bagi masyarakat (Mursalim \& Ramdani, 2016).

Kabupaten Blora membentuk tenaga ahli Program Pembangunan dan Pemberdayaan Masyarakat Desa (P3MD) yang berfungsi sebagai pendamping dan fasilitator bagi masyarakat desa untuk meningkatkan kemampuan pengetahuan, sikap, keterampilan, etika dan kesadaran dalam memanfaatkan dukungan dana desa untuk mengembangkan potensi desa. Keterlibatan pihak ketiga dalam pembangunan dan pemberdayaan masyarakat desa memiliki nilai tambah untuk membangun interaksi positif dan saling melengkapi yang dapat menunjang keterbukaan informasi bagi masyarakat dan mendorong kemampuan masyarakat dalam memanfaatkan dana desa untuk kemandirian desa. Hal ini sejalan dengan pendapat jurnal relevan yang mengemukakan bagaimana interaksi antar-sesama dapat meningkatkan keunggulan dalam berdaya saing dan mewujudkan capaian pembangunan yang sesuai tujuan (Widjajanti, 2011). Pemberdayaan masyarakat yang dijalankan di Kabupaten Blora melalui pemanfaatan dana desa mencakup dimensi perlindungan yang diberikan pemerintah.

Indikator keberhasilan dalam membangun keberdayaan masyarakat menjadi dasar bahwa dalam proses pembangunan kemandirian desa terutama di Kabupaten Blora perlu didukung oleh pemerintah. Dukungan tersebut dijalankan secara maksimal dengan adanya kerja sama untuk mengembangkan kemampuan masyarakat dalam memanfaatkan potensi yang tersedia. Melalui kesadaran yang memotivasi masyarakat untuk bergerak membangun kemandirian, diikuti dengan proses pengembangan kapasitas yang mengacu pada program dan kegiatan yang diselenggarakan serta mencakup tentang upaya perlindungan bagi masyarakat agar proses pembangunan berjalan secara berkelanjutan.

\subsubsection{Kendala dalam Pembangunan Kemandirian Desa Berbasis Masyarakat melalui Dukungan Dana Desa}

Pada pelaksanaannya, pembangunan kemandirian desa yang bertumpu pada masyarakat khususnya di Kabupaten Blora menjadi sasaran yang terus ditingkatkan prosesnya. Hal ini mengacu pada visi dan misi pembangunan daerah Kabupaten Blora, yaitu meningkatkan kesejahteraan masyarakat dengan mengoptimalkan pengembangan sumber daya yang berbasis pemberdayaan masyarakat secara berkelanjutan. Target pembangunan tersebut diimplementasikan dari tingkat desa sebagai tatanan pemerintahan yang secara langsung berinteraksi dengan masyarakat. Pembangunan desa di Kabupaten 
Blora dijalankan melalui berbagai indikator tujuan, salah satunya pengelolaan dana desa sebagai sumber pendanaan pembangunan. Dalam mencapai pembangunan tersebut pemerintah maupun masyarakat dihadapkan pada tantangan sekaligus hambatan, baik dari sisi internal maupun eksternal. Pengelolaan dana desa yang diarahkan khususnya pada bidang pemberdayaan masyarakat masih memerlukan perhatian pemerintah sebagai penyelenggara dan juga masyarakat sebagai subjek pemberdayaan. Tantangan mewujudkan pembangunan dan kemandirian desa menjadi bagian dalam proses yang menyebabkan adanya kendala-kendala dalam pembangunan kemandirian desa berbasis masyarakat terutama melalui dukungan dana desa di Kabupaten Blora. Desa harus berani untuk melakukan target pembangunan yang lebih besar dengan memetakan pengelolaan dana desa dalam pemenuhan program yang ditujukan bagi kesejahteraan masyarakat serta pembinaan baik secara sosial maupun ekonomi demi kesejahteraan masyarakat.

Kendala dan hambatan muncul dari faktor internal pada kapasitas Pemerintah Desa dalam melakukan pertanggungjawaban terhadap penggunaan dana desa yang diterima. Hal ini berkaitan dengan belum maksimalnya keterbukaan informasi mengenai pelaporan secara transparan dan mencakup pemanfaatan yang telah dihasilkan dari penyerapan dana desa yang disalurkan. Pentingnya wawasan bagi masyarakat dipengaruhi oleh aktifnya Pemerintah Desa dalam mengubah pola pikir masyarakat yang mengarah pada pengembangan kapasitas terutama dalam mengelola sumber daya. Persoalan ini akan berdampak pada tingginya tingkat ketergantungan masyarakat desa terhadap bantuan pemerintah dan akan menurunkan kemandirian masyarakat untuk membangun desa. Kemampuan masyarakat juga dilihat dari pengembangan yang bersifat partisipatif, peran aktif masyarakat yang tidak dijalankan secara berkala dan dalam jangka panjang akan menurunkan komitmen masyarakat dalam membangun kemandirian desa serta mengentaskan ketimpangan dan ketertinggalan desa. Permasalahan tersebut relevan dengan upaya pemberdayaan masyarakat dalam penelitian sebelumnya yang menjelaskan faktor penghambat dalam menunjang keberdayaan masyarakat mengacu pada lemahnya partisipasi masyarakat terutama dalam mengawal keberhasilan program yang diselenggarakan pemerintah (Rahman, 2016).

\section{PENUTUP}

Pada dasarnya, masyarakat akan lebih berdaya guna jika yang menjadi sasaran pembangunan berkaitan erat dengan kebutuhan bagi peningkatan taraf hidup mereka. Hal ini berkaitan dengan arti penting kerja sama yang bersifat jangka panjang dengan berlandaskan pada modal sosial masyarakat untuk menjalin relasi yang saling menguntungkan dengan pemerintah maupun kelembagaan, khususnya dalam tatanan desa. Melalui program dana desa yang diberikan secara berkala mencerminkan sikap pemerintah untuk mengupayakan pembangunan bagi masyarakat dengan optimal. Akan tetapi, yang menjadi permasalahan adalah besarnya harapan masyarakat yang menuntut kesejahteraan secara langsung.

Pada kasus ini, Kabupaten Blora memiliki keterbatasan dalam membangun kemandirian desa yang dipengaruhi oleh partisipasi dan komitmen masyarakat. Pemahaman mengenai pemberdayaan masyarakat dijelaskan melalui indikator keberhasilan meliputi dimensi pembentukan iklim yang memungkinkan masyarakat untuk berkembang. Dimensi ini mengacu pada upaya untuk meningkatkan kesadaran masyarakat agar berpartisipasi aktif dalam proses pembangunan desa, yang dilakukan oleh pemerintah dengan melibatkan masyarakat dalam penyusunan perencanaan pembangunan agar sesuai dengan kebutuhan masyarakat. Dimensi yang selanjutnya berkaitan dengan pengembangan kapasitas masyarakat agar lebih berdaya dan memiliki wawasan dan keahlian dalam 
mengelola sumber daya dan potensi lokal. Hal ini ditunjukkan dengan berbagai program dan kegiatan yang menggunakan modal dari dana desa di berbagai aspek pembangunan bagi kesejahteraan masyarakat. Selain itu, tingginya kesadaran dan kemampuan masyarakat harus diikuti dengan protecting dari pemerintah yang berperan sebagai pendamping dan fasilitator dalam pemberdayaan masyarakat. Perlindungan dari pemerintah dapat ditunjukkan dengan menetapkan kebijakan berupa peraturan maupun program mengenai tujuan penyaluran dana desa yang menunjang keberlangsungan pembangunan desa. Meninjau proses pembangunan di setiap dimensi, diperlukan adanya pemahaman dalam mendukung keberhasilan pemberdayaan masyarakat terutama melalui dana desa, menjadi prioritas untuk mendukung kemandirian desa yang berkelanjutan di Kabupaten Blora. Hal ini ditinjau dari upaya secara moral dengan membangun kesadaran masyarakat untuk berdaya guna melalui pengurangan pemberian bantuan secara langsung yang kemudian diarahkan pada pembangunan jenis usaha yang dikembangkan oleh desa dengan memprioritaskan individu-individu pada rumah tangga miskin. Selain itu, diperlukan adanya bina keluarga yang bertujuan untuk menunjang kapasitas masyarakat baik di bidang pendidikan, ekonomi, sosial, lingkungan, dan kesehatan secara bertahap dan menciptakan outcome guna menunjang kesejahteraan masyarakat. Berdasarkan indikator pemberdayaan masyarakat, Kabupaten Blora memiliki peluang untuk memaksimalkan penggunaan dana desa di bidang pemberdayaan masyarakat dalam membangun kemandirian desa. Peluang tersebut juga dijadikan sebagai upaya menghadapi tantangan yang muncul dari berbagai kendala dalam proses pembangunan desa.

Berdasarkan kajian yang telah diuraikan, penulis menyampaikan saran yang ditujukan kepada stakeholders dalam pembangunan desa, mencakup Pemerintah Daerah Kabupaten Blora dan Pemerintah Desa di Kabupaten Blora dalam menunjang keberhasilan pemberdayaan masyarakat yang dijalankan melalui dukungan dana desa sebagai stimulan dalam pengembangannya. Pada pelaksanaan pemberdayaan masyarakat yang dijalankan melalui dukungan dana desa perlu mencakup adanya akuntabilitas dan transparansi pelaporan penggunaan dana desa yang mengarah pada program kegiatan yang dirancang dengan evaluasi pencapaiannya. Hal ini perlu ditingkatkan dengan menjabarkan pemanfaatan dan realisasi dana desa bagi pembangunan kemandirian desa yang dijalankan untuk bidang pembangunan fisik dan pemberdayaan masyarakat secara terbuka. Program dan kegiatan yang ditetapkan lebih mengarah pada pencapaian yang mengacu pada kapasitas SDM secara jangka panjang dengan memanfaatkan potensi desa sebagai modal untuk mencapai kemandirian. Sedangkan untuk masyarakat desa di Kabupaten Blora, pada pelaksanaan pemberdayaan masyarakat berkaitan erat dengan dukungan dan keterlibatan kelembagaan desa sebagai power untuk menggerakkan masyarakat melalui prinsip kebersamaan. Upaya tersebut berkaitan dengan penguatan masyarakat untuk bergotong royong secara aktif dan partisipatif dalam mendorong pembangunan desa dan mewujudkan desa mandiri melalui pemanfaatan dana desa. Kemauan dan kemampuan dalam pembangunan desa menuju desa mandiri dan mengentaskan status desa tertinggal di suatu daerah menjadi kewajiban seluruh komponen guna optimalisasi sumber daya dan bertujuan meningkatkan kemandirian desa yang mampu berdaya saing dalam pengembangan potensi desa yang tersedia. Mengacu pada konsep dana desa, tidak terlepas dari kapasitas pemerintah dan SDM terkait, dari tingkat daerah maupun desa untuk mengoptimalkan pengawasan terhadap penggunaan dana desa di setiap desa agar mengetahui sejauh mana dana desa berdampak positif dalam pembangunan dan pemberdayaan masyarakat.

\section{DAFTAR PUSTAKA}

Barokah, H., Utami, D. R. W. W., \& Karmaji. (2015). Indeks Pembangunan Desa 2014: 
Tantangan Pemenuhan Standar Pelayanan Minimum Desa. Bappenas \& BPS.

Blora, D. P. K. (2019). Rencana Strategis Dinas Pemberdayaan Masyarakat dan Desa Kabupaten Blora Tahun 2017-2021.

BPS Blora. (2019). Statistik Daerah Kabupaten Blora 2019 (1101002.33). Badan Pusat Statistik Kabupaten Blora.

Creswell, J. W., \& Poth, C. N. (2016). Qualitative Inquiry and Research Design: Choosing Among Five Approaches. Sage Publications.

Diah, A., \& Syawie, M. (2015). Pembangunan Kemandirian Desa melalui Konsep Pemberdayaan: Suatu Kajian Dalam Perspektif Sosiologi. Jurnal Sosio Informa, 1 02, 175188.

Dwiyanto, B. S., \& Jemadi. (2013). Pemberdayaan Masyarakat dan Pengembangan Kapasitas Dalam Penanggulangan Kemiskinan Melalui Pnpm Mandiri Perkotaan. Jurnal Maksipreneur, III(1), 36-61.

Firmansyah, H. (2012). Ketercapaian Indikator Keberdayaan Masyarakat dalam Program Pemberdayaan Fakir Miskin ( P2FM ) di Kota Banjarmasin. Jurnal Agribisnis Perdesaan, 02(02), 170-180.

Friedman, J. (1992). Empowerment The Politics of Alternative Development. Blackwell Publishers.

Hasyim, N. M. (2019). Peningkatan Kemandirian Desa Panggungharjo Melalui Komunikasi Pembangunan. Jurnal Pemberdayaan Masyarakat: Media Pemikiran Dan Dakwah Pembangunan, 3(2), 352-376. https:/ / doi.org/10.14421/jpm.2019.032-06

Karimah, F., Saleh, C., \& Wanusmawatie, I. (2014). Pengelolaan Alokasi Dana Desa dalam Pemberdayaan Masyarakat (Studi pada Desa Deket Kulon Kecamatan Deket Kabupaten Lamongan). Jurnal Administrasi Publik (JAP), 2(4), 597-602.

Kemenkeu. (2017). Buku Saku Dana Desa: Dana Desa Untuk Kesejahteraan Rakyat. Kemenkeu RI.

Mafruhah, I. (2018). Manfaat Dana Desa di Provinsi Jawa Tengah. Badan Penelitian dan Pengembangan, Pendidikan dan Pelatihan, Kemendesa PDTT RI, LPPM UNS.

Mardhiah, N. (2017). Identifikasi Tujuan Dan Sasaran Pembangunan Desa Kabupaten Aceh Barat. Jurnal Public Policy, 3(1), 77-88. https:// doi.org/10.35308/jpp.v3i1.753

Mas'ud, M. F., \& Maesaroh. (2020). Pemberdayaan Masyarakat melalui Dana Desa di Desa Kulurejo Kecamatan Nguntoronadi Kabupaten Wonogiri. Journal of Public Policy and Management Review, 9(4), 1-13.

Maspaitella, M. J., \& Rahakbauwi, N. (2014). Pemberdayaan Masyarakat dalam Pendekatan Pekerja Sosial. Jurnal Aspirasi, 025, 157-164.

Miller, G. J., \& Whicker, M. L. (1998). Handbook of Research Methods in Public Administration. In Handbook of Research Methods in Public Administration. Marcel Dekker, Inc. https:/ / doi.org/10.4324/9780203908303

Mulyawan, R. (2016). Masyarakat, Wilayah, dan Pembangunan. UNPAD Press.

Mursalim, S. W., \& Ramdani, E. M. (2016). Pemberdayaan Masyarakat dalam Promosi Potensi Desa (Studi Kasus di Desa Parungserab Kabupaten Bandung). Jurnal Ilmu Administrasi, 13(2), 285-304.

Noverman, Y. (2018). Analisis Kesesuaian Pengelolaan Dana Desa dengan Peraturan Perundang-Undangan (Studi Kasus Di Nagari Bukit Bual Kabupaten Sijunjung). Jurnal Analisis Kebijakan Dan Pelayanan Publik, 4(2), 68-81.

PPID Kabupaten Blora. (2019). LPA PPKD: Laporan Realisasi Anggaran Pendaatan dan Belanja Tahun 2019. Pejabat Pengelola Informasi dan Dokuemntasi, Blora.

Prastiwi, D. A., Cahyaningtyas, A., \& Triana, D. (2019). Indeks Pembangunan Desa 2018 (Masfufah, T. Suryaningsih, \& A. Naim (eds.)). BPS.

Pusat Kajian Akuntabilitas Keuangan Negara, B. K. D. R. (2018). Kajian Dana Desa di Provinsi Jawa Tengah Tahun 2015-2017. Pusat Kajian Akuntabilitas Keuangan Negara Badan 
Keahlian DPR RI.

Rahman, K. (2016). Pemberdayaan Partisipasi Masyarakat Dalam Pembangunan Desa. Jurnal Pemerintahan, Politik Dan Birokrasi 189, II(1), 189-199.

Sofianto, A. (2017). Kontribusi Dana Desa terhadap Pembangunan dan Pemberdayaan Masyarakat di Kebumen dan Pekalongan. Matra Pembaruan, 1(1), 23-32. https:/ / doi.org/10.21787/mp.1.1.2017.23-32

Sofiyanto, M., Mardani, R. M., \& Salim, M. A. (2017). Pengelolaan Dana Desa dalam Upaya Meningkatkan Pembangunan di Desa Banyuates Kecamatan Banyuates Kabupaten Sampang. E - Jurnal Riset Manajemen, 6(4), 28-38.

Widjajanti, K. (2011). Model pemberdayaan masyarakat. Jurnal Ekonomi Pembangunan, 12(1), $15-27$.

Yang, K., \& Miller, G. J. (2007). Handbook of Research Methods in Public Administration: Second Edition. CRC Press, Taylor \& Francis Group. 